Article

\title{
Effects of Operational Parameters on Biofilm Formation of Mixed Bacteria for Hydrogen Fermentation
}

\author{
Jie Mei ${ }^{1,2}$, Huize Chen ${ }^{1,2}$, Qiang Liao ${ }^{1,2}$, Abdul-Sattar Nizami ${ }^{3}{ }^{(D}$, Ao Xia ${ }^{1,2}, * \mathbb{C}$, Yun Huang ${ }^{1,2}$, \\ Xianqing $\mathrm{Zhu}{ }^{1,2}$ and $\mathrm{Xun} \mathrm{Zhu}^{1,2}$ \\ 1 Key Laboratory of Low-grade Energy Utilization Technologies and Systems, Chongqing University, \\ Ministry of Education, Chongqing 400044, China; jiemei_92@163.com (J.M.); 20143580@cqu.edu.cn (H.C.); \\ lqzx@cqu.edu.cn (Q.L.); yunhuang@cqu.edu.cn (Y.H.); xianqingzhu@cqu.edu.cn (X.Z.); \\ zhuxun@cqu.edu.cn (X.Z.) \\ 2 Institute of Engineering Thermophysics, School of Energy and Power Engineering, Chongqing University, \\ Chongqing 400044, China \\ 3 Sustainable Development Study Centre, Government College University, Lahore 54000, Pakistan; \\ nizami_pk@yahoo.com \\ * Correspondence: aoxia@cqu.edu.cn
}

Received: 28 September 2020; Accepted: 22 October 2020; Published: 26 October 2020

\begin{abstract}
Dark fermentation of organic wastes, such as food waste and algae, via mixed hydrogen-producing bacteria (HPB) is considered a sustainable approach for hydrogen production. The biofilm system protects microorganisms from the harmful environment and avoids the excessive loss of bacteria caused by washout, which ensures that the dark fermentation process remains stable. In this study, a downflow anaerobic packed-bed reactor was commissioned to investigate the biofilm formation process of mixed HPB under various operational parameters. Scanning electron microscopy indicated changes in surface morphology during the biofilm formation period. Proteins and polysaccharides in extracellular polymeric substances were identified by confocal laser scanning microscopy to reveal their distribution characteristics. A hydraulic retention time of $0.5 \mathrm{~d}$, a substrate concentration of $15 \mathrm{~g} / \mathrm{L}$ and an HPB inoculum ratio of $35 \%$ were identified as the optimal operational parameters for biofilm formation. The diversity of bacteria between suspension and biofilm showed significantly different distributions; Clostridiales and Lactobacillales were identified as the dominant orders in the biofilm formation process. The abundances of Clostridiales and Lactobacillales were $15.1 \%$ and $56.2 \%$ in the biofilm, respectively.
\end{abstract}

Keywords: dark fermentation; biofilm formation; hydrogen production; mixed bacteria; sustainability

\section{Introduction}

Hydrogen has received widespread attention worldwide because of its clean combustion characteristics (only water is a product) and high calorific value $(142 \mathrm{MJ} / \mathrm{kg}$ ) $[1,2]$. At present, fossil fuel reforming and water electrolysis are the major hydrogen production methods, which can produce hydrogen at a large scale. However, fossil fuel resources are nonrenewable, and overexploitation of fossil fuels has led to energy shortages. Traditional hydrogen production is energy intensive and expensive. For example, water electrolysis consumes much electricity, which increases the cost of hydrogen production [3]. Such deficiencies limit the sustainability of hydrogen production. In contrast, the process of producing hydrogen through dark fermentation by hydrogen-producing bacteria (HPB) is advantageous for low energy consumption [4]. In addition, dark fermentation of biomass wastes (such as agricultural and forestry waste, livestock manure, food waste, algae and organic wastewater) 
can not only relieve the pressure of fossil energy supply but also provide significant environmental benefits [5]. Although hydrogen production by dark fermentation has been established over several decades, such a technology is still in its infancy stage and has not yet been commercialized.

Dark fermentation is usually carried out in HPB suspension culture to improve the mass transfer between bacteria and organic substrates [6]. However, significant losses of microorganisms may be observed at a short hydraulic retention time (HRT) when wastewater with a low organic concentration is treated, with the result that the fermentation system cannot be operated efficiently and stably [7]. Shin and Youn studied the fermentation of food wastes with a low organic concentration under various HRTs $(48,72$ and $120 \mathrm{~h}$ ) and found that $120 \mathrm{~h}$ had the highest hydrogen production, while significant washout of HPB was observed at short HRTs [8].

Using biofilm technology in place of suspension culture can reduce the loss of HPB while improving the ability of bacteria to respond to changes in the external environment [9]. Keskin et al. examined the continuous hydrogen production between the suspension and biofilm systems. The results indicated that the performance of the biofilm reactor in hydrogen production and resistance to cell washout was better than that of the suspension reactor. Meanwhile, the solid loss of the suspension reactor was approximately seven times higher than that of the biofilm reactor [10]. Ma et al. investigated the hydrogen production between Bacillus cereus and Brevumdimonas naejangsanensis based on biofilm technology. They found that the average cumulative hydrogen production and hydrogen yield were $62.5 \%$ higher than the suspended fermentation. Biofilm also helps to achieve long-term repeated use of bacteria, to shorten the HRT of the fermentation system and to maintain a high fermentation performance in long-term efficient fermentation [11].

The process of biofilm formation is affected by many factors, such as characteristics of the carrier surface, concentration of substrate, HRT, $\mathrm{pH}$, temperature, and inoculum concentration of bacteria [12]. Langer et al. studied biofilm formation and dynamics via various microscopic techniques to obtain the thickness of the biofilm, biofilm-covered surface area, and area covered by extracellular polymeric substances (EPS). They found that increasing the concentration of substrate could increase the number of microorganisms, which could improve the ability to degrade organic matter [13]. The selection of different types of biofilm carrier materials also had a significant influence on the initial adhesion properties of microorganisms. Identifying suitable supporting materials would be very beneficial for both the start-up and stable stages of anaerobic digestion [14]. Several existing studies have focused on improving performance of the biofilm system during the fermentation process $[15,16]$. Understanding the basics of the biofilm formation process would be important to reveal the mechanisms of fermentation enhancement by biofilms. However, most of the studies on biofilm formation have employed monoculture [17,18], and information on mixed cultures of HPB biofilm formation is quite limited. To the best of our knowledge, the effects of operational parameters on mixed HPB biofilm formation have rarely been reported.

Different operational parameters would lead to biofilms with various microstructures; the microstructure has a huge impact on the mass transfer of the substrate and products, which further affects the thermodynamics and kinetics of biochemical reactions in the biofilm, thereby affecting the fermentative hydrogen production performance $[19,20]$. Picioreanu et al. found that irregularities and mass transfer rates of the monoculture biofilm surface had enormous effects on the diffusion of substances and the growth of microorganisms by simulating the biofilm transfer process based on a two-dimensional model [21]. Zhu et al. reported that the biofilm microstructure showed significant resistance for gas and liquid mass transfer via microelectrode and microscopic techniques [22]. However, knowledge about the influence of operating parameters on the microstructure of mixed HPB biofilms and the distribution of active substances is relatively lacking, which is not advantageous for the further exploration of the transfer and conversion of organics in biofilm fermentation systems.

The innovation of this study is to comprehensively study the impacts of key parameters, such as the hydraulic retention time, substrate concentration and inoculum ratio, on the biofilm formation process of HPB mixed cultures. The main purpose of this study is to obtain the optimal parameters 
for HPB biofilm formation, to investigate the microstructure and the distribution of active substances in mixed culture HPB biofilms and to understand the interactions between various bacteria in the process of mixed HPB biofilm formation, which would provide guidance for operation of an HPB biofilm reactor.

\section{Materials and Methods}

\subsection{Inoculum and Substrate}

The mixed HPB was obtained from activated sludge from a rural biogas digester in Chongqing, China. To enrich mixed HPB, the sludge was filtered to remove the large particle residues and heated at $100{ }^{\circ} \mathrm{C}$ for $30 \mathrm{~min}$ in an autoclave to inactivate the methanogens. The hydrogen-producing medium was employed to acclimate HPB. This acclimation was conducted at least 3 times with an interval of 3-5 d each time, while the HPB was maintained at $35.0 \pm 0.5^{\circ} \mathrm{C}$ in a water bath to obtain highly active bacteria, and the mixed HPB was used as a fermentation inoculum. Hydrogen production medium was modified according to a previous study [23], and the concentrations $(\mathrm{g} / \mathrm{L})$ were as follows: glucose 10, yeast 2, L-cysteine $0.5, \mathrm{NaCl} 3, \mathrm{~K}_{2} \mathrm{HPO}_{4} 2.5, \mathrm{MgCl}_{2} \cdot 6 \mathrm{H}_{2} \mathrm{O} 0.2, \mathrm{FeCl}_{2} \cdot 4 \mathrm{H}_{2} \mathrm{O} 0.15$, trace element solution $10 \mathrm{~mL}$, and vitamin solution $10 \mathrm{~mL}$.

\subsection{Experimental System and Scheme Design}

The experimental system was mainly composed of a downflow anaerobic packed-bed reactor, a culture medium bottle, a peristaltic pump, an effluent bottle and a gas tank (as shown in Figure 1). Silicon carbide $(\mathrm{SiC})$ was used as the carrier of biofilm because of its chemically inert nature and large surface roughness. Before connecting the components, the $\mathrm{SiC}$ was soaked with sodium hypochlorite or $75 \mathrm{v} \%$ alcohol solution to eliminate viruses and bacteria and then cleaned with deionized water for later use. The temperature of the HPB growth process was controlled at $35.0 \pm 0.5^{\circ} \mathrm{C}$. Nitrogen gas was flushed for $10 \mathrm{~min}$ to ensure an anaerobic environment. In the experiments, the HRTs were set as $0.5-3.5 \mathrm{~d}$, the concentrations of substrate were set as $5-45 \mathrm{~g} / \mathrm{L}$, and the HPB inoculum ratios were set as $5-35 \%$.

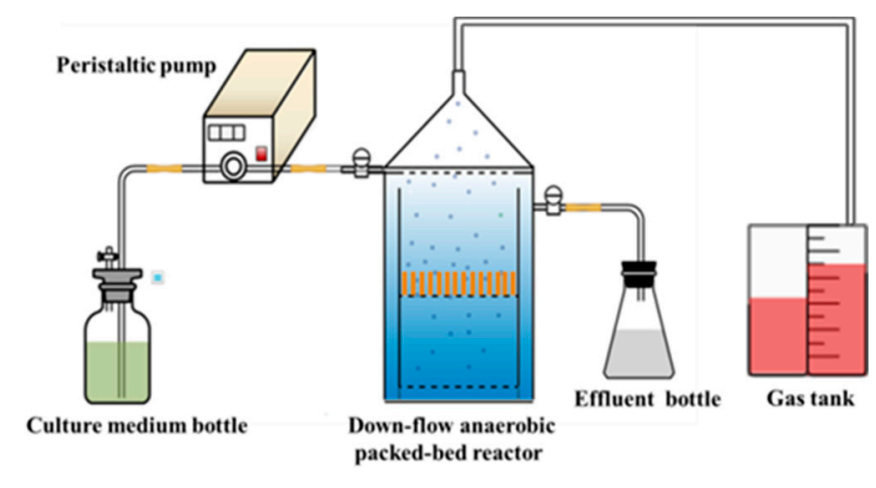

Figure 1. Schematic diagram of the experimental system.

\subsection{Biofilm Substance Analysis}

The dry weight (DW) of the biofilm was obtained via the weight difference before and after biofilm formation. The samples were dried at $105^{\circ} \mathrm{C}$ for $24 \mathrm{~h}$ to remove moisture after being removed from the bioreactor [24].

EPS were attached to the surface of the carrier that must be extracted for effective testing [25]. The biofilm carrier was placed in the $\mathrm{NaCl}$ solution at a concentration of $10.85 \%$ and shocked for $2 \mathrm{~min}$ via an ultrasonic vibration device. After vibration, the carrier was removed and placed in a shaker at $150 \mathrm{r} / \mathrm{min}$ for $10 \mathrm{~min}$. The carrier was shocked by the same shaker for another $2 \mathrm{~min}$. Then, the carrier was centrifuged at $8000 \times g$ for $10 \mathrm{~min}$, and the supernatant was taken to measure the content of EPS. 
The EPS is mainly composed of proteins and polysaccharides. The contents of extracellular proteins and polysaccharides were determined via the Coomassie Brilliant Blue and anthrone-sulfuric acid method as described in previous studies [26,27].

\subsection{Biofilm Structure Analysis}

After removing the biofilm carrier from the reactor, the carrier was gently rinsed 2-3 times with deionized water to remove impurities. Then, the samples were soaked with $2.5 \mathrm{v} . \%$ glutaraldehyde solution for $60 \mathrm{~min}$. Subsequently, the samples were removed and soaked in ethanol solutions with concentrations of $10 \mathrm{v} . \%, 30 \mathrm{v} . \%, 50 \mathrm{v} . \%, 70 \mathrm{v} . \%$ and $90 \mathrm{v} \%$ for $20 \mathrm{~min}$ to complete the gradient dehydration. Finally, a mixed solution of ethanol and tert-butyl alcohol $(1 / 1, v / v)$ and pure tert-butyl alcohol was used to dehydrate the samples, and the dehydrated samples were dried in a desiccator [28]. Biofilm samples were sprayed with gold, and the morphology and biofilm formation process of the carrier surface were visually observed by SEM (TESCAN, VEGA 3 LMH, Brno, Czech Republic).

Extracellular proteins were labeled by fluorescein isothiocyanate (FITC) reagent, and extracellular polysaccharides were labeled by ConA reagent. Subsequently, confocal laser scanning microscopy (CLSM) (Leica, TCS SP8, Wetzlar, Germany) was employed to reveal the three-dimensional structure of the bacterial biofilm and the variation of extracellular proteins and polysaccharides during the experimental period. A layer scanning image is obtained every $2 \mu \mathrm{m}$ along the thickness of the biofilm. The excitation light wavelength was $488 \mathrm{~nm}$, and the emission wave wavelength was $500-550 \mathrm{~nm}$ to observe the labeled proteins. Moreover, an excitation light wavelength of $561 \mathrm{~nm}$ and an emission wave wavelength of 570-590 nm were set to observe the labeled polysaccharides [29].

\subsection{Microflora Analysis}

The tested samples were from the suspension and the biofilm on the carrier surface for analysis of the microbial diversity. DNA was extracted by using the PowerSoil ${ }^{\circledR}$ DNA Isolation Kit (MoBio Laboratories Inc., Carlsbad, CA, USA) according to the manufacturer's instructions, which were then stored at $-20{ }^{\circ} \mathrm{C}$ before use [30]. The bacterial $16 \mathrm{~S}$ rRNA genes in the V3-V4 regions were amplified by the primer sequences 338F (5'-ACTCCTACGGGAGGCAGCA-3 ${ }^{\prime}$ ) and 806R (5'-GGACTACVSGGGTATCTAAT-3') [31]. Microflora analysis was completed by BioMarker Biotechnology Co., Ltd. Illumina HiSeq 2500 was employed for the $16 \mathrm{~S}$ rRNA gene sequencing. Raw sequences were assembled, screened and then trimmed. Sequences obtained in the clone libraries were assigned as different operational taxonomic units (OTU; each OTU represented 97\% sequence identity).

\section{Results}

\subsection{Effects of Different HRTs on Biofilm Formation}

Figure 2 shows the changes in dry weight, extracellular protein and polysaccharide contents at different HRTs. When the HRT was set at $3.5 \mathrm{~d}$, the DW of the biofilm on the carrier slowly increased to $4.1 \mathrm{~g} / \mathrm{m}^{2}$ over time to $2 \mathrm{~d}$. Meanwhile, the extracellular protein and polysaccharide contents increased to 0.01 and $0.39 \mathrm{~g} / \mathrm{m}^{2}$, respectively. As the time further increased to $8 \mathrm{~d}$, the DW increased to $21.7 \mathrm{~g} / \mathrm{m}^{2}$, the extracellular protein content increased to $0.2 \mathrm{~g} / \mathrm{m}^{2}$, and the extracellular polysaccharide content increased to $1.0 \mathrm{~g} / \mathrm{m}^{2}$. The $\mathrm{pH}$ of the effluent dropped significantly to approximately 4.5 . 


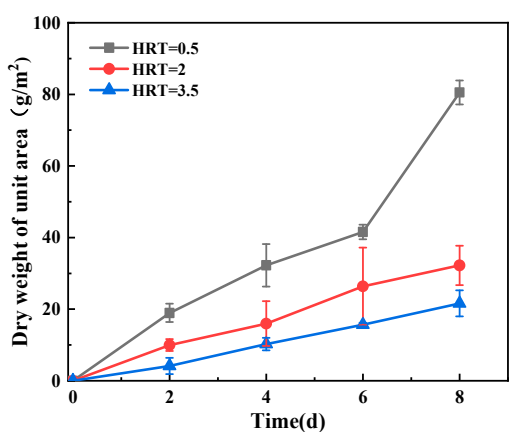

(a)

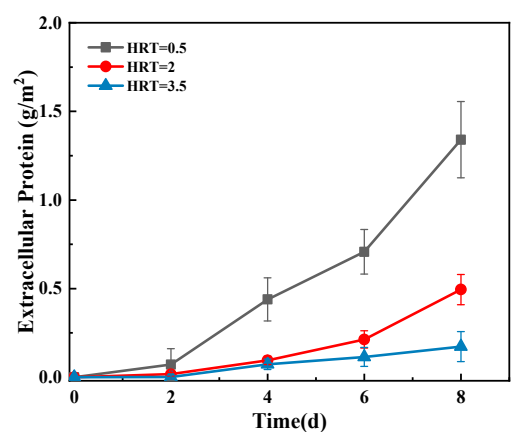

(b)

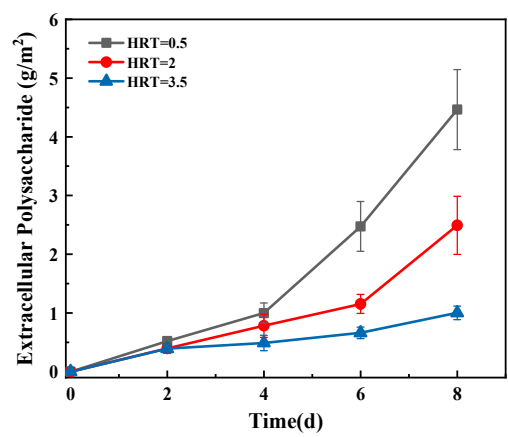

(c)

Figure 2. Changes in dry weight, extracellular protein and polysaccharide contents at different hydraulic retention times (HRTs): (a) Dry weight; (b) Extracellular protein; (c) Extracellular polysaccharide.

When the HRT was reduced to $2 \mathrm{~d}$, the DW of the biofilm gradually increased with time. The final DW of the biofilm reached $32.2 \mathrm{~g} / \mathrm{m}^{2}$, which showed a $48.4 \%$ increase compared with the HRT of $3.5 \mathrm{~d}$. At the same time, the contents of proteins and polysaccharides reached 0.5 and $2.5 \mathrm{~g} / \mathrm{m}^{2}$, respectively, which showed a significant increase compared with 0.2 and $1.0 \mathrm{~g} / \mathrm{m}^{2}$ under the HRT of $3.5 \mathrm{~d}$. This phenomenon showed that the content of extracellular substances and DW could be increased by reducing the HRT from $3.5 \mathrm{~d}$ to $2 \mathrm{~d}$.

When further reducing the HRT to $0.5 \mathrm{~d}$, the maximum DW of the HPB biofilm reached $81.2 \mathrm{~g} / \mathrm{m}^{2}$, which was 3.7 times higher than the HRT of $3.5 \mathrm{~d}$. Similarly, the contents of extracellular proteins and polysaccharides reached up to 1.3 and $4.5 \mathrm{~g} / \mathrm{m}^{2}$, respectively, which were 6.5 and 4.5 times higher than the HRT of $3.5 \mathrm{~d}$. The results suggested that the changing trend of biofilm dry weight was consistent with the changing patterns of extracellular proteins and polysaccharides.

Figure 3 displays the SEM and CLSM images of mixed HPB on the carrier surface at different HRTs. The biomass on the surface of the $\mathrm{SiC}$ carrier increased with growth time, and the morphology of the HPB biofilm on the surface was more complete and denser at a lower HRT. In contrast, a loose and porous morphology was exhibited at higher HRTs, and the biomass was also reduced accordingly. When the HRT was $0.5 \mathrm{~d}$, the areas of the proteins and polysaccharides covered on the carriers were the largest, and the fluorescence intensity shown in the field of view was the highest by CLSM observation, which also indicated that the HPB secreted the most extracellular substances under such conditions. 

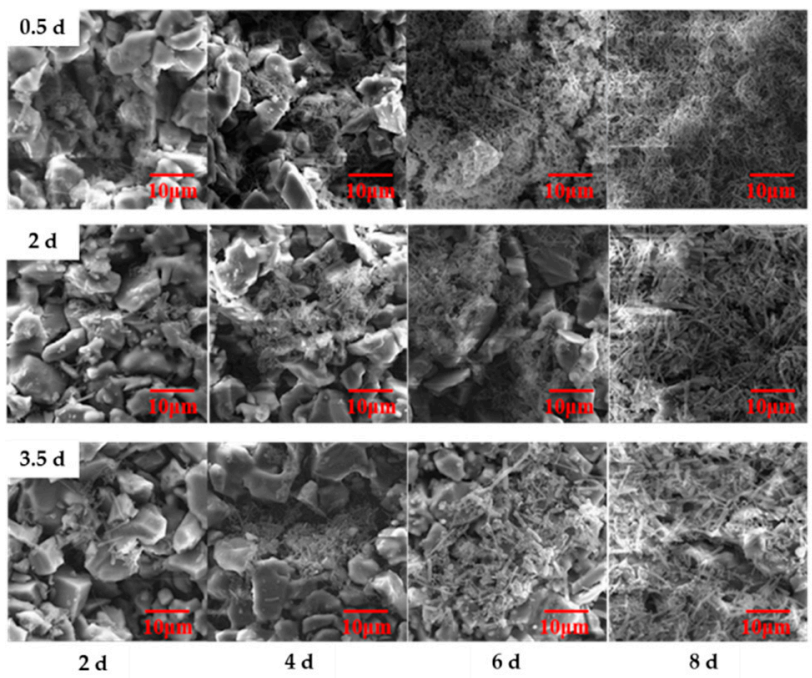

(a)
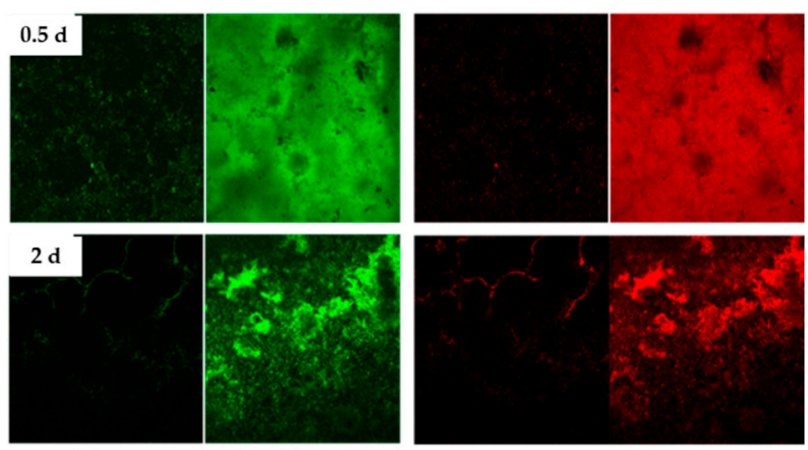

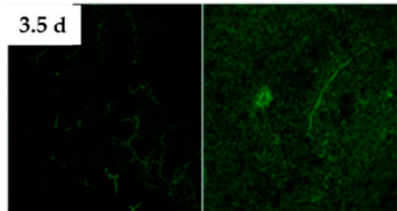

$2 \mathrm{~d}$

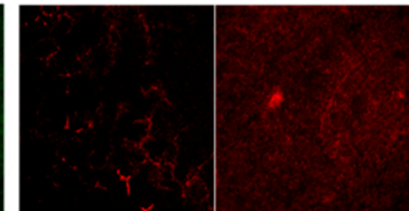

$2 \mathrm{~d}$

$8 \mathrm{~d}$

(b)

Figure 3. SEM and CLSM images of mixed HPB on the carrier surface at different HRTs: (a) SEM; (b) CLSM.

\subsection{Effects of Different Substrate Concentrations on the Biofilm Formation}

The effect of glucose concentration $(5-45 \mathrm{~g} / \mathrm{L})$ on biofilm formation is shown in Figure 4 . With increasing glucose concentration in culture medium, the area densities of dry weight, extracellular proteins, and polysaccharides showed trends of first increasing and then decreasing. When the glucose concentration was $5 \mathrm{~g} / \mathrm{L}$, the values of DW, extracellular proteins and polysaccharides were at the lowest levels. At the end of the experiment (8th day), the maximum DW of HPB biofilm reached $30.9 \mathrm{~g} / \mathrm{m}^{2}$, and the contents of extracellular proteins and polysaccharides reached $0.5 \mathrm{~g} / \mathrm{m}^{2}$ and $2.4 \mathrm{~g} / \mathrm{m}^{2}$, respectively. 


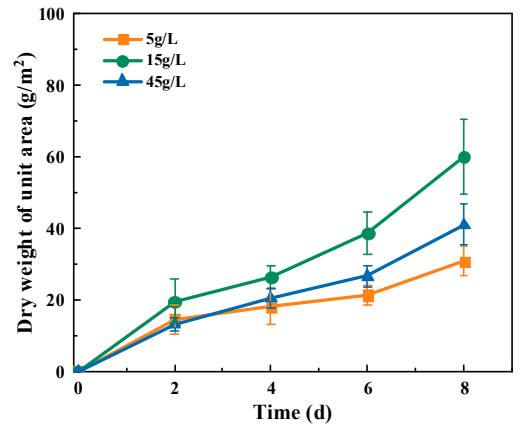

(a)

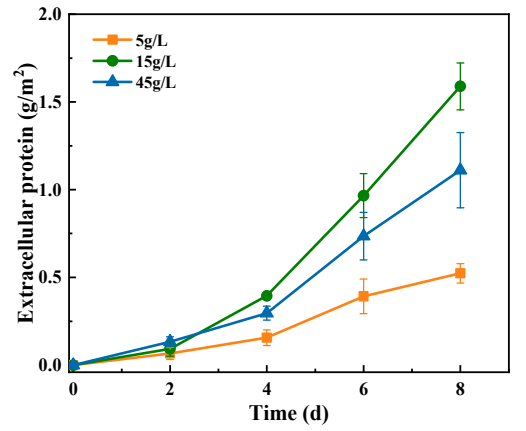

(b)

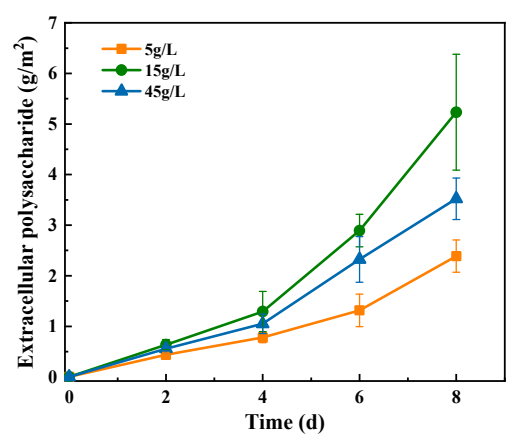

(c)

Figure 4. Changes in dry weight, extracellular protein and polysaccharide contents at different substrate concentrations: (a) Dry weight; (b) Extracellular protein; (c) Extracellular polysaccharide.

Based on the above results, increasing the substrate concentration would promote bacterial activity and improve the amount of HPB adsorbed on the surface of the SiC carrier. When the concentration increased to $15 \mathrm{~g} / \mathrm{L}$ at the beginning of this experiment $(0-2 \mathrm{~d})$, the values of $\mathrm{DW}$, proteins, and polysaccharides were not much different from the values of $5 \mathrm{~g} / \mathrm{L}$. However, on the 8th day, the values of DW, proteins, and polysaccharides increased significantly, reaching up to 60.1, 1.6 , and $5.2 \mathrm{~g} / \mathrm{m}^{2}$, respectively, which were $1.9,3.2$, and 2.1 times larger than the concentration of $5 \mathrm{~g} / \mathrm{L}$. However, as the substrate concentration was further increased to $45 \mathrm{~g} / \mathrm{L}$, biofilm growth was inhibited. The DW, protein content, and polysaccharide weight were decreased.

Figure 5 displays the surface morphology and substance distribution of biofilms on the carrier. On the 2nd day, only a small amount of biomass appeared on the carrier. With increasing experimental time, HPB attached to the carrier were scattered from rare to gradually covering the entire surface. On the 8th day, a relatively dense HPB biofilm, most of which was observed as rod-shaped bacteria, had formed on the carrier when the substrate concentration was $15 \mathrm{~g} / \mathrm{L}$. CLSM revealed that the distribution of proteins and polysaccharides was the widest, and the fluorescence intensity was the highest at $15 \mathrm{~g} / \mathrm{L}$. 


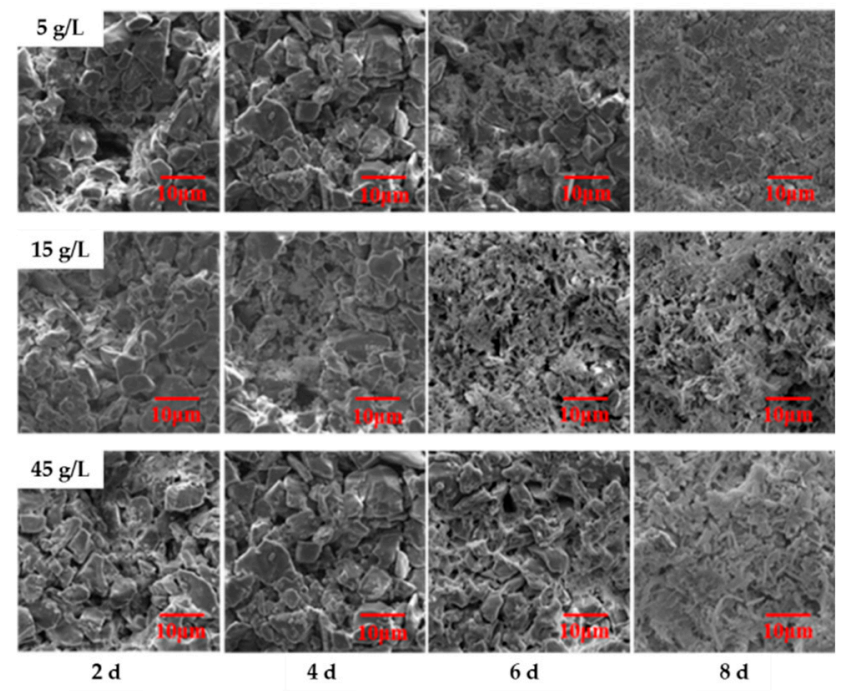

(a)
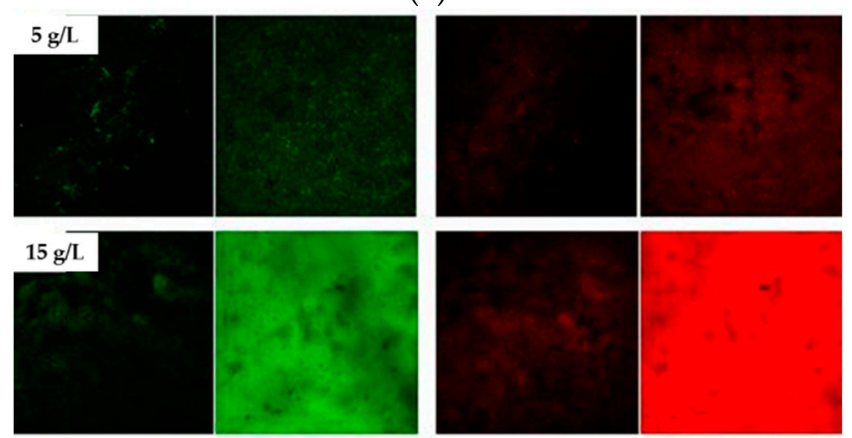

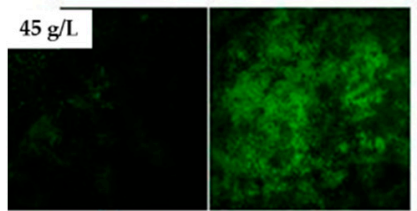

$2 d$

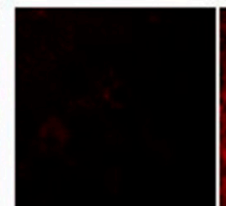

$2 \mathrm{~d}$

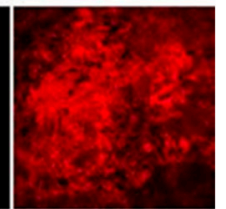

$8 \mathrm{~d}$

(b)

Figure 5. SEM and CLSM images of mixed HPB on the carrier surface at different substrate concentrations: (a) SEM; (b) CLSM.

\subsection{Effects of Different Inoculum Ratios on Biofilm Formation}

The inoculum ratios of mixed HPB were set as 5\%, 20\% and 35\% to study the biofilm formation process. Figure 6 shows the changes in DW, extracellular protein and polysaccharide contents at different inoculum ratios. The growth rate of biofilm DW was very slow during the biofilm formation process when the inoculum ratio was $5 \%$. The value of maximum DW at the end of the experiment (the 8th day) was only $35.4 \mathrm{~g} / \mathrm{m}^{2}$. Similarly, the contents of extracellular proteins and polysaccharides were also low, at only 0.5 and $1.8 \mathrm{~g} / \mathrm{m}^{2}$, respectively.

At the initial $2 \mathrm{~d}$, the values of DW, extracellular proteins, and polysaccharides were not significantly different. As the formation time increased to $4 \mathrm{~d}$, the DW of the biofilm on the carrier surface increased significantly when the inoculum ratios were increased to $20 \%$ and $35 \%$. The values of maximum DW reached 59.2 and $62.1 \mathrm{~g} / \mathrm{m}^{2}$, respectively. The contents of extracellular proteins $\left(1.0\right.$ and $\left.1.2 \mathrm{~g} / \mathrm{m}^{2}\right)$ and polysaccharides ( 3.6 and $4.6 \mathrm{~g} / \mathrm{m}^{2}$ ) measured were significantly increased compared with the inoculum ratio of $5 \%$. 


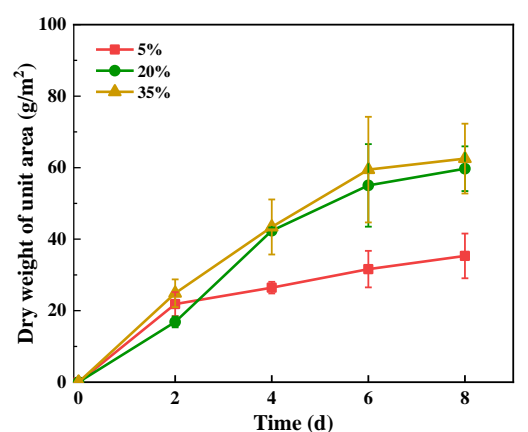

(a)

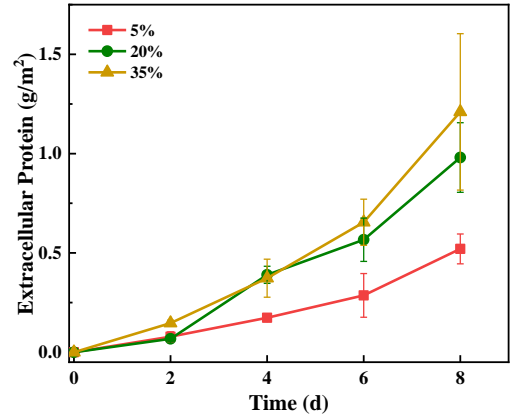

(b)

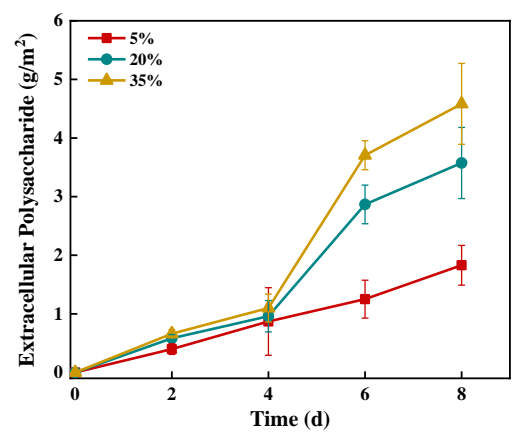

(c)

Figure 6. Changes in dry weight, extracellular protein and polysaccharide contents at different inoculum ratios: (a) Dry weight; (b) Extracellular protein; (c) Extracellular polysaccharide.

The biofilm was scanned layer by layer along with its thickness by CLSM to complete the 3D reconstruction. Figure 7 displays the 3D images of extracellular proteins and polysaccharides on the biofilm carrier. With the increase in the inoculum ratio of HPB, the fluorescence intensity and the color rendering area on the carrier increased accordingly. The thicknesses of the proteins and polysaccharides attached to the carrier were approximately $40-70 \mu \mathrm{m}$.

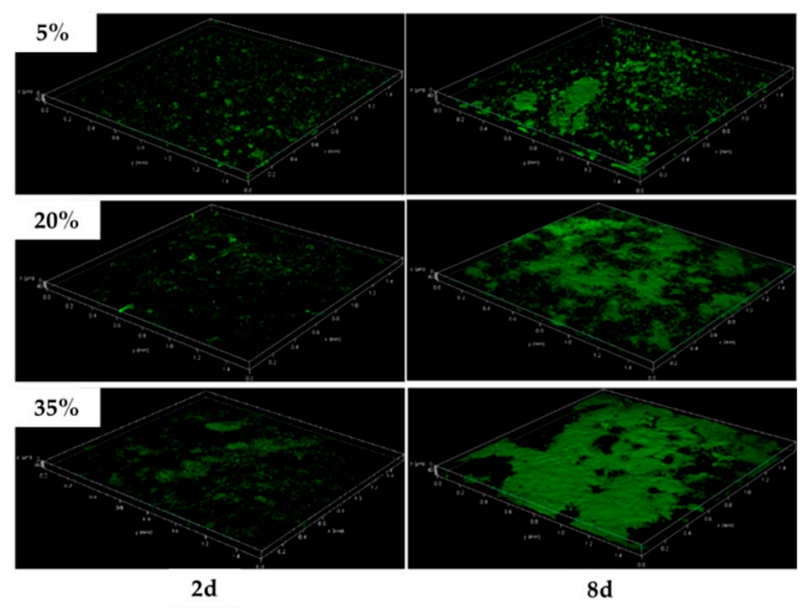

(a)

Figure 7. Cont. 


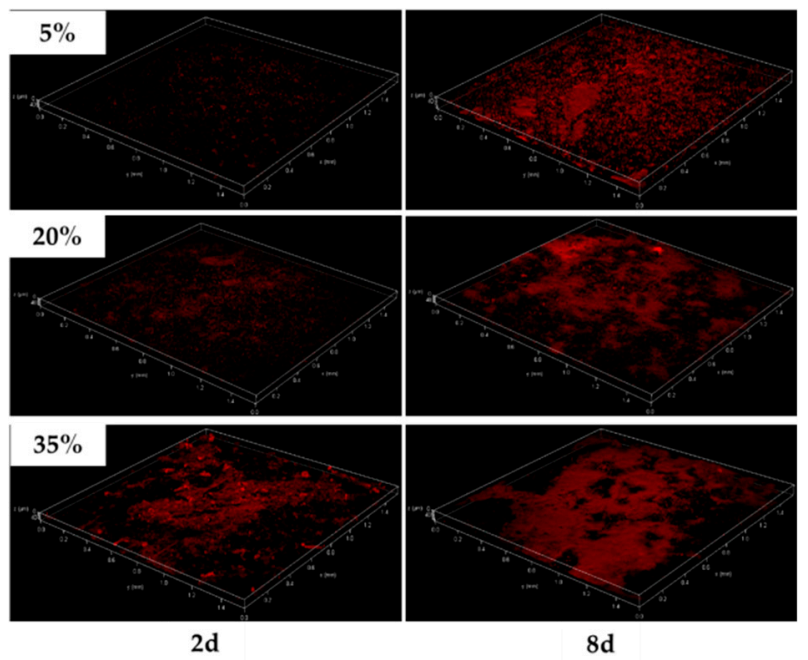

(b)

Figure 7. Three-dimensional images of the distribution of secreted substances on biofilm carriers at different inoculum ratios: (a) extracellular protein; (b) extracellular polysaccharide.

Figure 8 shows the microflora analysis on the carrier surface and suspension. There are three dominant orders including Clostridiales, Lactobacillales and Enterobacteriales. The abundances of these three orders in the suspension were $36.8 \%, 40.1 \%$ and $14.5 \%$, respectively. The abundances of these three orders in the biofilms were $15.1 \%, 56.2 \%$ and $9.2 \%$, respectively.

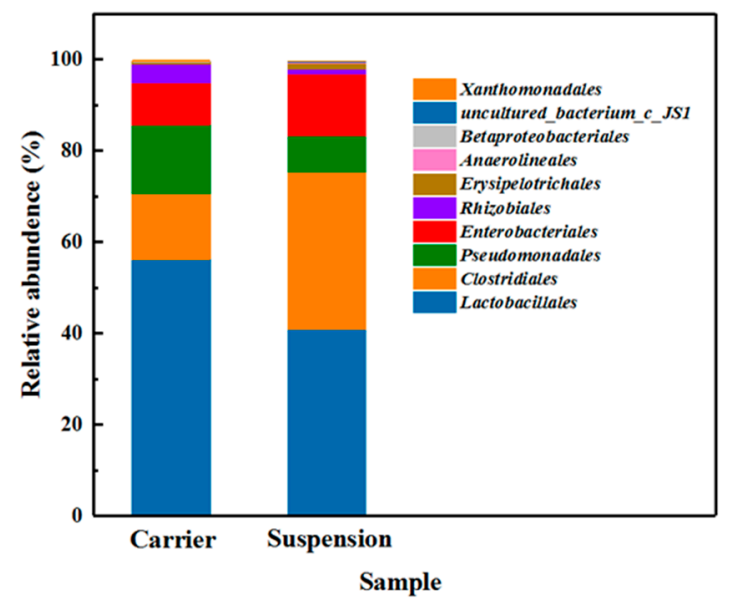

Figure 8. Microflora analysis on carrier surface and suspension

\section{Discussion}

\subsection{Biofilm Formation Characteristics}

In the early stage of biofilm formation, HPB was reversibly adsorbed on the surface of the carrier, mainly through deposition or free movement. Meanwhile, the amount of secreted material was very low and did not support significant HPB adhesion to form biofilms. With increasing time, HPB adapted to the environment and secreted more EPS. EPS mainly played the role of biological glue and skeleton in the structure of the biofilm, which provided resistance against the hydraulic shear force. During the experiment, high HRT may not be an advantage for formation. Low flow rate caused by high HRT is unfavorable for product release in reactors. And the accumulation of volatile fatty acid (VAFs) produced by microbial metabolic processes result in acidification of the entire reaction system, which is proven by the low $\mathrm{pH}$ value of the effluent. Consequently, the activity of mixed HPB was severely inhibited, 
leading to EPS secretion and slow biofilm formation. With the hydraulic retention time shortened to 0.5 days, the increase rate of DW, extracellular proteins and polysaccharides were significantly improved, especially in the period of 6-8 $\mathrm{d}$. That is because the nutrients were being well used for growth and reproduced by HPB in suitable environment as well as gradually forming a relatively stable biofilm system. Moreover, the suspension growth is minimal under low HRT condition, which made the biofilms have relatively more nutrient to grow [32]. In addition, the VFAs produced by bacterial metabolism could be effectively removed at a high flow rate. The inhibition of HPB activity at low $\mathrm{pH}$ was lifted so that more EPS could be secreted, which could promote the adhesion of HPB on the carrier surface [33]. Overall, the result of these experimental studies indicated a lower HRT was an advantage for mixed HPB biofilm formation.

Substrate concentration also had huge influence on the formation of HPB biofilm. Compared with biofilms under $15 \mathrm{~g} / \mathrm{L}$ substrate concentration conditions, the growth rate under $5 \mathrm{~g} / \mathrm{L}$ was relatively low, mainly because HPB could not obtain sufficient nutrients [34], to reproduce and metabolize at low substrate concentration, which resulted in low bacterial activity and adverse effects biofilm formation [35]. However, the formation of biofilm is inhibited when the substrate concentration further reaches $45 \mathrm{~g} / \mathrm{L}$. These phenomena are related to the quick degradation of a large amount of glucose into VFAs [36,37]. The excessive accumulation of VFAs led to a rapid decrease in the $\mathrm{pH}$ value of the biofilm microenvironment, which would cause acidification of the system and inhibit the biological activity of HPB in the reactor [38]. The process of biofilm formation has been limited.

The loss of HPB caused by washout resulted in not enough bacteria attaching to the surface of the carriers when the inoculation ratio was low, which led to a reduction in the amount of extracellular secretions produced by HPB. As the inoculation ratio increased, the negative effect of bacterial loss was weakened. High inoculation ratio made the bioreactor system have sufficient bacteria to complete the biofilm formation process and enhanced biofilm formation. Additionally, the image taken by CLSM also showed that increasing the inoculation ratio made the bioreactor system have more bacteria to produce EPS adhered to the surface of the carrier, which led to the accumulation of EPS and strengthened the biofilm formation.

\subsection{Bacterial Diversity of Mixed HPB}

Clostridiales, as the dominant order, was common to see in hydrogen production process. Im et al. studied the hydrogen production performance of food waste and sewage sludge in a mesophilic environment and found that Clostridiales was the main bacterial order after $2 \mathrm{~d}$ [39]. Hernández-Mendoza et al. discovered that discontinuous and continuous processes led to different microbial community diversities, and Clostridiales had greater abundance in continuous processes [40]. Lactobacillales was another dominant bacteria in the continuous bioreactor [41] and has been proven to have a strong relationship with hydrogen production performance, which can promote hydrogen production [42,43]. Lactic acid, as a possible product of Lactobacillales, might be converted to acetic acid in anaerobic and acidic environments [44].

Moreover, Lactobacillales and Clostridiales could form a stable co-metabolism. The lactic acid produced by Lactobacillales degrading glucose could be converted to pyruvate by lactate dehydrogenase. Pyruvate could participate in the butyric acid metabolism process completed by Clostridiales [45]. The abundance of Lactobacillales and Clostridiales in biofilm and suspension is very different, which can be explained by the microenvironment formed in the biofilm. Acid-producing bacteria may cause a gradient distribution of $\mathrm{pH}$ in the biofilm [46] and Lactobacillales has stronger acid tolerance than Clostridiales [47,48]. Therefore, Lactobacillus was relatively more adaptable to the environmental conditions in the biofilm, showing greater abundance.

Enterobacteriales also showed a relatively high abundance because the inoculum of this study came from a rural biogas digester that treated livestock manures and Enterobacteriales, as a typical order in the gut, has been reported to have a positive correlation with ethanol and formate production 
in dark fermentation [49], and formate could be further consumed to produce $\mathrm{H}_{2}$ by formate hydrogen lyase [50].

\subsection{Practical Implications of this Study}

Recent studies have demonstrated biofilm technology as a means for enhancing hydrogen fermentation performance [51,52]. However, most existing studies focus on finding optimal operating parameters under specific conditions to improve the performance of biohydrogen production [53,54], which is usually accomplished on a macro scale, ignoring the microscopic mechanism of biofilms in reactors. This study investigated the enhancement strategy of HPB biofilms in the formation period. There are still many other challenges in the practical implications of HPB biofilm technology. For example, the dense biofilm structure may cause mass transfer resistance [22,55], which is not conducive to the utilization of substrates and the release of toxic products. Stable attachment of biofilms requires a longer start-up period [56]. Compared with traditional reactors, biofilms have higher requirements for reactor design. These challenges require future studies of biofilms on a micro scale, focusing on the heterogeneous structure, mass transfer process and physiological activity within the biofilm. A better understanding of anaerobic fermentation biofilms is helpful for applying the optimized HPB biofilm for efficient fermentative hydrogen production in continuous bioreactors.

\section{Conclusions}

The formation of HPB biofilms could be effectively enhanced by regulating environmental parameters during the growth of biofilms. The optimal HRT of $0.5 \mathrm{~d}$, glucose concentration of $15 \mathrm{~g} / \mathrm{L}$, and inoculum ratio of $35 \%$ were identified, respectively. SEM and CLSM revealed that the biomass and extracellular substances were most widely distributed on the carrier surface under the optimal conditions. The dominant orders of Clostridiales and Lactobacillus were identified in the biofilm, which can co-metabolize glucose into hydrogen and VFAs.

Author Contributions: Conceptualization, J.M. and A.X.; Methodology, J.M.; Software, J.M. and H.C.; Validation, J.M.; Investigation, J.M. and H.C.; Funding acquisition, A.X.; Data curation, J.M.; Writing-original draft preparation, J.M.; Writing—review and editing, A.X., Q.L., A.-S.N., Y.H., X.Z. (Xianqing Zhu) and X.Z. (Xun Zhu); Visualization, J.M. and H.C. All authors have read and agreed to the published version of the manuscript.

Funding: This work was supported by the National Key Research and Development Program of China (No. 2018YFB1501401), the National Natural Science Foundation of China (Nos. 51876016, 51836001, 51606021), and the Fundamental Research Funds for the Central Universities (Nos. 2020CDJQY-A054, 2018CDPTCG0001/18).

Conflicts of Interest: The authors declare no conflict of interest.

\section{References}

1. Noblecourt, A.; Christophe, G.; Larroche, C.; Santa-Catalina, G.; Trably, E.; Fontanille, P. High hydrogen production rate in a submerged membrane anaerobic bioreactor. Int. J. Hydrogen Energy 2017, 42, 24656-24666. [CrossRef]

2. Xia, A.; Cheng, J.; Ding, L.; Lin, R.; Song, W.; Su, H.; Zhou, J.; Cen, K. Substrate consumption and hydrogen production via co-fermentation of monomers derived from carbohydrates and proteins in biomass wastes. Appl. Energy 2015, 139, 9-16. [CrossRef]

3. Holladay, J.D.; Hu, J.; King, D.L.; Wang, Y. An overview of hydrogen production technologies. Catal. Today 2009, 139, 244-260. [CrossRef]

4. Mamimin, C.; Prasertsan, P.; Kongjan, P.; Sompong, O. Effects of volatile fatty acids in biohydrogen effluent on biohythane production from palm oil mill effluent under thermophilic condition. Electron. J. Biotechnol. 2017, 29, 78-85. [CrossRef]

5. Xia, A.; Cheng, J.; Murphy, J.D. Innovation in biological production and upgrading of methane and hydrogen for use as gaseous transport biofuel. Biotechnol. Adv. 2016, 34, 451-472. [CrossRef]

6. Weiland, P. Biogas production: Current state and perspectives. Appl. Microbiol. Biotechnol. 2010, 85, 849-860. [CrossRef] 
7. Ren, N.; Guo, W.; Liu, B.; Cao, G.; Ding, J. Biological hydrogen production by dark fermentation: Challenges and prospects towards scaled-up production. Curr. Opin. Biotechnol. 2011, 22, 365-370. [CrossRef]

8. Shin, H.-S.; Youn, J.-H. Conversion of food waste into hydrogen by thermophilic acidogenesis. Biodegradation 2005, 16, 33-44. [CrossRef] [PubMed]

9. Guo, W.-Q.; Ren, N.-Q.; Wang, X.-J.; Xiang, W.-S. Accelerated startup of biological hydrogen production process by addition of Ethanoligenens harbinense B49 in a biofilm-based column reactor. Int. J. Hydrogen Energy 2010, 35, 13407-13412. [CrossRef]

10. Keskin, T.; Giusti, L.; Azbar, N. Continuous biohydrogen production in immobilized biofilm system versus suspended cell culture. Int. J. Hydrogen Energy 2012, 37, 1418-1424. [CrossRef]

11. Ma, Z.; Li, C.; Su, H. Dark bio-hydrogen fermentation by an immobilized mixed culture of Bacillus cereus and Brevumdimonas naejangsanensis. Renew. Energy 2017, 105, 458-464. [CrossRef]

12. Barca, C.; Soric, A.; Ranava, D.; Giudici-Orticoni, M.-T.; Ferrasse, J.-H. Anaerobic biofilm reactors for dark fermentative hydrogen production from wastewater: A review. Bioresour. Technol. 2015, 185, 386-398. [CrossRef] [PubMed]

13. Langer, S.; Schropp, D.; Bengelsdorf, F.R.; Othman, M.; Kazda, M. Dynamics of biofilm formation during anaerobic digestion of organic waste. Anaerobe 2014, 29, 44-51. [CrossRef] [PubMed]

14. Nguyen, V.; Karunakaran, E.; Collins, G.; Biggs, C.A. Physicochemical analysis of initial adhesion and biofilm formation of Methanosarcina barkeri on polymer support material. Colloids Surf. B 2016, 143, 518-525. [CrossRef]

15. Karadag, D.; Köroğlu, O.E.; Ozkaya, B.; Cakmakci, M. A review on anaerobic biofilm reactors for the treatment of dairy industry wastewater. Process Biochem. 2015, 50, 262-271. [CrossRef]

16. Martí-Herrero, J.; Alvarez, R.; Rojas, M.; Aliaga, L.; Céspedes, R.; Carbonell, J. Improvement through low cost biofilm carrier in anaerobic tubular digestion in cold climate regions. Bioresour. Technol. 2014, 167, 87-93. [CrossRef]

17. Wang, Y.-J.; Liao, Q.; Wang, Y.-Z.; Zhu, X.; Li, J. Effects of flow rate and substrate concentration on the formation and $\mathrm{H} 2$ production of photosynthetic bacterial biofilms. Bioresour. Technol. 2011, 102, 6902-6908. [CrossRef]

18. Liao, Q.; Wang, Y.-J.; Wang, Y.-Z.; Chen, R.; Zhu, X.; Pu, Y.-K.; Lee, D.-J. Two-dimension mathematical modeling of photosynthetic bacterial biofilm growth and formation. Int. J. Hydrogen Energy 2012, 37, 15607-15615. [CrossRef]

19. Chen, M.; Zhang, Z.; Bott, T. Effects of operating conditions on the adhesive strength of Pseudomonas fluorescens biofilms in tubes. Colloids Surf. B 2005, 43, 61-71. [CrossRef]

20. Wijeyekoon, S.; Mino, T.; Satoh, H.; Matsuo, T. Effects of substrate loading rate on biofilm structure. Water Res. 2004, 38, 2479-2488. [CrossRef]

21. Picioreanu, C.; Van Loosdrecht, M.C.; Heijnen, J.J. Effect of diffusive and convective substrate transport on biofilm structure formation: A two-dimensional modeling study. Biotechnol. Bioeng. 2000, 69, 504-515. [CrossRef]

22. Zhu, X.; Suidan, M.; Alonso, C.; Yu, T.; Kim, B.; Kim, B. Biofilm structure and mass transfer in a gas phase trickle-bed biofilter. Water Sci. Technol. 2001, 43, 285-293. [CrossRef] [PubMed]

23. Cheng, J.; Xia, A.; Song, W.; Su, H.; Zhou, J.; Cen, K. Comparison between heterofermentation and autofermentation in hydrogen production from Arthrospira (Spirulina) platensis wet biomass. Int. J. Hydrogen Energy 2012, 37, 6536-6544. [CrossRef]

24. Hamano, H.; Nakamura, S.; Hayakawa, J.; Miyashita, H.; Harayama, S. Biofilm-based photobioreactor absorbing water and nutrients by capillary action. Bioresour. Technol. 2017, 223, 307-311. [CrossRef]

25. Comte, S.; Guibaud, G.; Baudu, M. Relations between extraction protocols for activated sludge extracellular polymeric substances (EPS) and EPS complexation properties: Part I. Comparison of the efficiency of eight EPS extraction methods. Enzym. Microb. Technol. 2006, 38, 237-245. [CrossRef]

26. Jain, S.; Chen, J. Antibiotic resistance profiles and cell surface components of salmonellae. J. Food Prot. 2006, 69, 1017-1023. [CrossRef] [PubMed]

27. Chen, L.; Ren, Z.; Zhou, X.; Zeng, J.; Zou, J.; Li, Y. Inhibition of Streptococcus mutans biofilm formation, extracellular polysaccharide production, and virulence by an oxazole derivative. Appl. Microbiol. Biotechnol. 2016, 100, 857-867. [CrossRef] 
28. Zhang, L.; Zhou, S.; Zhuang, L.; Li, W.; Zhang, J.; Lu, N.; Deng, L. Microbial fuel cell based on Klebsiella pneumoniae biofilm. Electrochem. Commun. 2008, 10, 1641-1643. [CrossRef]

29. Adav, S.S.; Chun-Te Lin, J.; Yang, Z.; Whiteley, C.G.; Lee, D.-J.; Peng, X.-F.; Zhang, Z.-P. Stereological assessment of extracellular polymeric substances, exo-enzymes, and specific bacterial strains in bioaggregates using fluorescence experiments. Biotechnol. Adv. 2010, 28, 255-280. [CrossRef]

30. Li, Q.; Guo, X.; Lu, Y.; Shan, G.; Huang, J. Impacts of adding FGDG on the abundance of nitrification and denitrification functional genes during dairy manure and sugarcane pressmud co-composting. Waste Manag. 2016, 56, 63-70. [CrossRef]

31. Ping, Q.; $\mathrm{Lu}, \mathrm{X}$.; Zheng, $\mathrm{M}$.; Li, Y. Effect of $\mathrm{CaO}_{2}$ addition on anaerobic digestion of waste activated sludge at different temperatures and the promotion of valuable carbon source production under ambient condition. Bioresour. Technol. 2018, 265, 247-256. [CrossRef]

32. Heijnen, J.; Van Loosdrecht, M.; Mulder, A.; Tijhuis, L. Formation of biofilms in a biofilm air-lift suspension reactor. Water Sci. Technol. 1992, 26, 647-654. [CrossRef]

33. Wei, P.; Xia, A.; Liao, Q.; Sun, C.; Huang, Y.; Fu, Q.; Zhu, X.; Lin, R. Enhancing fermentative hydrogen production with the removal of volatile fatty acids by electrodialysis. Bioresour. Technol. 2018, 263, 437-443. [CrossRef] [PubMed]

34. Cresson, R.; Carrère, H.; Delgenes, J.P.; Bernet, N. Biofilm formation during the start-up period of an anaerobic biofilm reactor-Impact of nutrient complementation. Biochem. Eng. J. 2006, 30, 55-62. [CrossRef]

35. Sun, C.; Xia, A.; Liao, Q.; Fu, Q.; Huang, Y.; Zhu, X.; Wei, P.; Lin, R.; Murphy, J.D. Improving production of volatile fatty acids and hydrogen from microalgae and rice residue: Effects of physicochemical characteristics and mix ratios. Appl. Energy 2018, 230, 1082-1092. [CrossRef]

36. Bundhoo, M.Z.; Mohee, R. Inhibition of dark fermentative bio-hydrogen production: A review. Int. J. Hydrogen Energy 2016, 41, 6713-6733. [CrossRef]

37. Xia, A.; Jacob, A.; Tabassum, M.R.; Herrmann, C.; Murphy, J.D. Production of hydrogen, ethanol and volatile fatty acids through co-fermentation of macro-and micro-algae. Bioresour. Technol. 2016, 205, 118-125. [CrossRef]

38. Elbeshbishy, E.; Dhar, B.R.; Nakhla, G.; Lee, H.-S. A critical review on inhibition of dark biohydrogen fermentation. Renew. Sustain. Energy Rev. 2017, 79, 656-668. [CrossRef]

39. Im, W.-T.; Kim, D.-H.; Kim, K.-H.; Kim, M.-S. Bacterial community analyses by pyrosequencing in dark fermentative $\mathrm{H} 2$-producing reactor using organic wastes as a feedstock. Int. J. Hydrogen Energy 2012, 37, 8330-8337. [CrossRef]

40. Hernandez-Mendoza, C.E.; Moreno-Andrade, I.; Buitron, G. Comparison of hydrogen-producing bacterial communities adapted in continuous and discontinuous reactors. Int. J. Hydrogen Energy 2014, 39, 14234-14239. [CrossRef]

41. Palomo-Briones, R.; Celis, L.B.; Méndez-Acosta, H.O.; Bernet, N.; Trably, E.; Razo-Flores, E. Enhancement of mass transfer conditions to increase the productivity and efficiency of dark fermentation in continuous reactors. Fuel 2019, 254, 115648. [CrossRef]

42. Kim, T.-H.; Lee, Y.; Chang, K.-H.; Hwang, S.-J. Effects of initial lactic acid concentration, HRTs, and OLRs on bio-hydrogen production from lactate-type fermentation. Bioresour. Technol. 2012, 103, 136-141. [CrossRef] [PubMed]

43. Yang, P.; Zhang, R.; McGarvey, J.A.; Benemann, J.R. Biohydrogen production from cheese processing wastewater by anaerobic fermentation using mixed microbial communities. Int. J. Hydrogen Energy 2007, 32, 4761-4771. [CrossRef]

44. Elferink, S.J.O.; Krooneman, J.; Gottschal, J.C.; Spoelstra, S.F.; Faber, F.; Driehuis, F. Anaerobic conversion of lactic acid to acetic acid and 1, 2-propanediol by Lactobacillus buchneri. Appl. Environ. Microbiol. 2001, 67, 125-132. [CrossRef]

45. Tsukahara, T.; Koyama, H.; Okada, M.; Ushida, K. Stimulation of butyrate production by gluconic acid in batch culture of pig cecal digesta and identification of butyrate-producing bacteria. J. Nutr. 2002, 132, 2229-2234. [CrossRef]

46. Fulaz, S.; Hiebner, D.; Barros, C.H.; Devlin, H.; Vitale, S.; Quinn, L.; Casey, E. Ratiometric Imaging of the in Situ pH Distribution of Biofilms by Use of Fluorescent Mesoporous Silica Nanosensors. ACS Appl. Mater. Interfaces 2019, 11, 32679-32688. [CrossRef] 
47. Benito, Á; Calderón, F.; Benito, S. Schizosaccharomyces pombe and Lachancea thermotolerans: Joint Use as an Alternative to the Traditional Fermentations by Saccharomyces cerevisiae and Oenococcus oeni in Oenology. In Alcoholic Beverages; Holban, A.M., Grumezescu, A.M., Eds.; Elsevier: Amsterdam, The Netherlands, 2019; pp. 387-417.

48. Ghoddusi, H.B.; Sherburn, R.E.; Aboaba, O.O. Growth limiting pH, water activity, and temperature for neurotoxigenic strains of Clostridium butyricum. ISRN Microbiol. 2013, 731430. [CrossRef]

49. Palomo-Briones, R.; Razo-Flores, E.; Bernet, N.; Trably, E. Dark-fermentative biohydrogen pathways and microbial networks in continuous stirred tank reactors: Novel insights on their control. Appl. Energy 2017, 198, 77-87. [CrossRef]

50. Cabrol, L.; Marone, A.; Tapia-Venegas, E.; Steyer, J.-P.; Ruiz-Filippi, G.; Trably, E. Microbial ecology of fermentative hydrogen producing bioprocesses: Useful insights for driving the ecosystem function. FEMS Microbiol. Rev. 2017, 41, 158-181. [CrossRef]

51. Hiligsmann, S.; Beckers, L.; Masset, J.; Hamilton, C.; Thonart, P. Improvement of fermentative biohydrogen production by Clostridium butyricum CWBI1009 in sequenced-batch, horizontal fixed bed and biodisc-like anaerobic reactors with biomass retention. Int. J. Hydrogen Energy 2014, 39, 6899-6911. [CrossRef]

52. Chiranjeevi, P.; Kumar, A.N.; Mohan, S.V. Critical assessment of biofilm and suspended growth reactor configurations for acidogenic biohydrogen production using wastewater as a function of redox microenvironment. Int. J. Hydrogen Energy 2014, 39, 7561-7571. [CrossRef]

53. Santos, S.C.; Rosa, P.R.F.; Sakamoto, I.K.; Varesche, M.B.A.; Silva, E.L. Organic loading rate impact on biohydrogen production and microbial communities at anaerobic fluidized thermophilic bed reactors treating sugarcane stillage. Bioresour. Technol. 2014, 159, 55-63. [CrossRef] [PubMed]

54. Pasupuleti, S.B.; Sarkar, O.; Mohan, S.V. Upscaling of biohydrogen production process in semi-pilot scale biofilm reactor: Evaluation with food waste at variable organic loads. Int. J. Hydrogen Energy 2014, 39, 7587-7596. [CrossRef]

55. Ordaz, A.; Ramirez, R.; Hernandez-Martinez, G.R.; Carrión, M.; Thalasso, F. Characterization of kinetic parameters and mass transfer resistance in an aerobic fixed-bed reactor by in-situ respirometry. Biochem. Eng. J. 2019, 146, 194-202. [CrossRef]

56. Özkaya, B.; Kaksonen, A.H.; Sahinkaya, E.; Puhakka, J.A. Fluidized bed bioreactor for multiple environmental engineering solutions. Water Res. 2019, 150, 452-465. [CrossRef]

Publisher's Note: MDPI stays neutral with regard to jurisdictional claims in published maps and institutional affiliations.

(C) 2020 by the authors. Licensee MDPI, Basel, Switzerland. This article is an open access article distributed under the terms and conditions of the Creative Commons Attribution (CC BY) license (http://creativecommons.org/licenses/by/4.0/). 